\title{
Study of the Synthesis of Zirconia Powder from Zircon Sand obtained from Zircon Minerals Malaysia by Caustic Fusion Method
}

\author{
Istikamah Subuki ${ }^{1 *}$, Mimi Fazzlinda Mohsin ${ }^{1}$, Muhammad Hussain Ismail ${ }^{2}$, and Fazira Suriani \\ Mohamed Fadzil ${ }^{4}$
}

${ }^{1}$ Faculty of Chemical Engineering, Universiti Teknologi MARA, 40450 Shah Alam, Selangor, Malaysia

${ }^{2}$ Faculty of Mechanical Engineering, Universiti Teknologi MARA, 40450 Shah Alam, Selangor, Malaysia

${ }^{3}$ Industrial Centre of Innovation Nanotechnology, SIRIM Industrial Research, Lot 34,

Jl. Hi-Tech 2/3, Kulim Hi-Tech Park, 09000 Kulim, Kedah, Malaysia

\section{* Corresponding author:}

email: istikamah@uitm.edu.my

Received: March 4, 2019

Accepted: August 9, 2019

DOI: $10.22146 / \mathrm{ijc} .43936$

\begin{abstract}
The zircon powder from Zircon Minerals Malaysia is a pure premium grade zircon sand milled $1.5 \mu \mathrm{m}$ that contain $\mathrm{ZrSiO}_{4}, \mathrm{ZrO}_{2}, \mathrm{HfO}_{2}, \mathrm{SiO}_{2}, \mathrm{Al}_{2} \mathrm{O}_{3}, \mathrm{TiO}_{2}$, and $\mathrm{Fe}_{2} \mathrm{O}_{3}$. The monoclinic zirconia powders were synthesized from the zircon sand of Zircon Minerals Malaysia, by caustic fusion method at calcination temperatures between $500{ }^{\circ} \mathrm{C}$ to $800{ }^{\circ} \mathrm{C}$. The as-synthesized zirconia was characterized through X-Ray diffraction (XRD), scanning electron microscopy (SEM), thermogravimetric and differential thermal analysis (TG-DTA), and X-Ray fluorescence (XRF) techniques. The XRD results show two monoclinic phases of microcrystalline zirconia. Zirconia that was calcined at $600{ }^{\circ} \mathrm{C}$ obtained the highest value of $\mathrm{ZrO}_{2}$, which was 54.48\%; followed by zirconia calcined at 700, 800, and $500{ }^{\circ} \mathrm{C}$, which obtained the $\mathrm{ZrO}_{2}$ values of 53.58, 52.41, and 51.53\%, respectively, based on the XRF analysis. As-synthesized zirconia showed monoclinic phases where the surface areas were $0.0635 \mathrm{~g}, 0.135,0.0268$, and $0.0288 \mathrm{~m}^{2} / \mathrm{g}$, for zirconia calcined at temperatures of $500,600,700$, and $800{ }^{\circ} \mathrm{C}$, respectively. The surface structure of the powder that had been calcined at $600^{\circ} \mathrm{C}$ showed similarities with the commercial zirconia. The similarities of the synthesized zirconia and commercial zirconia showed that the zirconia powder could be synthesized using zircon sand by caustic fusion method, even though the content of zirconia was lower compared to that of the commercial zirconia powder.
\end{abstract}

Keywords: zirconia; zircon sand; monoclinic; caustic fusion method

\section{- INTRODUCTION}

Zirconia $\left(\mathrm{ZrO}_{2}\right)$ powder is a white crystalline known as zirconium oxide. This powder is chemically inert and can withstand high temperatures, corrosion, and thermal shock [1]. The condition of the zirconia can either be in natural form or processed form. Zirconium oxide is the condition when the zirconia is in the natural form, known as mineral baddeleyite. The zirconia is calcined to high temperatures to produce zirconia oxide. Many researchers are interested in studying the zirconia powder because it is widely used in ceramic materials and many applications, such as in dentistry, scaffold bone tissue engineering, and enamels [2]. The melting point of the natural zirconia as mineral baddeleyite is high, which is $2715^{\circ} \mathrm{C}$, and its boiling point is $4300^{\circ} \mathrm{C}$, which makes the toughness of the zirconia very high [3]. Zirconia has unique properties because of its complex and temperature-dependent phase transition. Pure zirconia exists in three crystal phases: monoclinic, cubic, and tetragonal, depending on the temperature [4]. The material can have sharp edges and a very smooth surface when the powder is in fine grain size. However, the weakness of the zirconia in its physical characteristics is shown during phase change, when it is heated [5]; the addition of stabilizers can overcome this problem. Yttria partially stabilized zirconia

Istikamah Subuki et al. 
exists when the yttrium oxide is added as a stabilizer, making it one of the solutions in solving this problem [6].

There are several methods to produce zirconia powder, such as hydrothermal oxidation, thermal decomposition, precipitation, and hydrolysis [7]. The method used to produce different characteristics of zirconia powder is based on the desired product. The best result obtained for zirconia powder is using chemical routes, but it is not an economical method for industrial manufacturing compared to the conventional milling method [8]. However, the high-quality nanometer-sized powder is obtainable using the technology of precipitation. Nevertheless, these powders are relatively expensive even though it produces high purity zirconia. Zircon can be used to overcome the problem because zircon is the main mineral precursor. Zircon is the main type of heavy mineral species, and it can be found at the beach along the coast of Brazil [9]. In industrial minerals, zircon is commercially important. The use of zircon in the production of zirconia is quickly increasing because it is capable of resisting high temperatures and chemical attacks, creating good refractory for furnaces, steel ladles, and foundry sand used [10]. The production of zirconia is simple, and it requires low capital and operational cost by concentrating the zircon through caustic fusion [11-12]. These facts show that the caustic method is essential for compound production. The fusion method is generally used to synthesize the zirconia from zircon. In this method, different chemicals can be used, such as sodium hydroxide, and calcium carbonate. However, sodium hydroxide is commonly used in caustic fusion method for the production of zirconium oxide or zirconia. Thus, in this study, to synthesize the zirconia powder, zircon sand will be used to produce high purity and economical zirconia by using caustic fusion method.

\section{- EXPERIMENTAL SECTION}

\section{Materials}

Table 1 shows the chemical composition of Australian Zircon sand obtained from the Zircon Minerals Malaysia. The commercial zirconia powder was obtained from Vistee Technology Services.
Table 1. Chemical composition of zircon sand

\begin{tabular}{lc}
\hline Name of substances & Composition percent $(\%)$ \\
\hline Zirconia + Hafnia $\left(\mathrm{ZrO}_{2}+\mathrm{HfO}_{2}\right)$ & 64.2 \\
Silica $(\mathrm{SiO})$ & 33.8 \\
Alumina $\left(\mathrm{Al}_{2} \mathrm{O}_{3}\right)$ & 0.90 \\
Titania $\left(\mathrm{TiO}_{2}\right)$ & 0.14 \\
Iron Oxide $\left(\mathrm{Fe}_{2} \mathrm{O}_{3}\right)$ & 0.06 \\
\hline
\end{tabular}

\section{Instrumentation}

Analysis were conducted to evaluate the physical and chemical characterizations of all of the synthesized zirconia powders. The thermal behavior of the powders was analyzed by thermogravimetric and differential thermal analysis (Mettler Toledo TGA/DSC SDTA851). The powders were then heated from room temperature to $1000{ }^{\circ} \mathrm{C}$ at a heating rate of $10{ }^{\circ} \mathrm{C} / \mathrm{min}$ in a flowing nitrogen atmosphere. Ultima IV Rigaku X-Ray diffractometer was used at a scan speed of $2{ }^{\circ} \mathrm{C} / \mathrm{min}$ over a scan range between $10^{\circ}-90^{\circ}$ to examine the phase that is present in the powder. The particle size distribution of the powder was measured using Malvern Instrument type Mastersizer 2000. Brunauer-Emmett-Teller (BET) analysis was used to measure the specific surface area, and X-Ray fluorescence (XRF) PAN Analytical Axios was used to determine the chemical composition in the powder. The surface structure of the powders was assessed using a scanning electron microscopy (SEM) image (Zeiss LEO 1525).

\section{Procedure}

\section{Synthesis of zirconia powder}

The zirconia was synthesized by using the caustic fusion method. $\mathrm{NaOH}$ was weighed at $30 \mathrm{~g}$ and zircon at $33 \mathrm{~g}$ [13]. The weight was determined by calculating the number of moles according to the chemical reaction below [13]:

$$
\begin{aligned}
& \mathrm{ZrSiO}_{4(\mathrm{~s})}+4 \mathrm{NaOH}_{(\mathrm{s})} \\
& \stackrel{\text { Caustic fusion }}{\longrightarrow} \mathrm{Na}_{2} \mathrm{ZrO}_{3(\mathrm{~s})}+\mathrm{Na}_{2} \mathrm{SiO}_{3}+2 \mathrm{H}_{2} \mathrm{O}_{(\mathrm{g})}
\end{aligned}
$$

Next, the acid leaching method was used to produce $\mathrm{ZrOCl}_{2}$ by dissolving the mixture in $120 \mathrm{~mL}$ of $5 \mathrm{M} \mathrm{HCl}$ solution. The process was conducted at $85^{\circ} \mathrm{C}$ for $30 \mathrm{~min}$. Then, the $\mathrm{ZrOCl}_{2}$ produced was reacted with 
$\mathrm{NH}_{4} \mathrm{OH} 1 \mathrm{M}$ until the $\mathrm{pH}$ of the solution becomes 9 to obtain the $\mathrm{Zr}(\mathrm{OH})_{4}$.

$$
\stackrel{\mathrm{ZrOCl}_{2(1)}+2 \mathrm{NH}_{4} \mathrm{OH}_{(1)}}{\stackrel{\text { Precipitation }}{\longrightarrow}} \mathrm{ZrO}(\mathrm{OH})_{2(\mathrm{~s})}+2 \mathrm{NH}_{4} \mathrm{Cl}_{(1)}
$$

The process was done by stirring at $90{ }^{\circ} \mathrm{C}$. The $\mathrm{Zr}(\mathrm{OH})_{2}$ was produced after $24 \mathrm{~h}$, and then filtered and washed using hot water to get a $\mathrm{pH}$ solution of 7 . Before the zirconia powder was obtained by the calcination process, the residue was heated at $150^{\circ} \mathrm{C}$ for $3 \mathrm{~h}$ to remove the moisture content [13].

$$
\begin{aligned}
& \mathrm{ZrO}(\mathrm{OH})_{2(\mathrm{~s})} \stackrel{\text { Dried at } 150^{\circ} \mathrm{C}}{\longrightarrow} \mathrm{ZrO}(\mathrm{OH})_{2(\mathrm{~s})}+\mathrm{H}_{2} \mathrm{O}_{(\mathrm{g})} \\
& \text { Wet } \\
& \text { Dry }
\end{aligned}
$$

The calcination process was done at $800{ }^{\circ} \mathrm{C}$ for $5 \mathrm{~h}$ and repeated with different temperatures which were 500 , 600 , and $700{ }^{\circ} \mathrm{C}$.

$$
\mathrm{ZrO}(\mathrm{OH})_{2(\mathrm{~s})} \stackrel{\text { Calcined at } 800^{\circ} \mathrm{C}}{\longrightarrow} \mathrm{ZrO}_{2(\mathrm{~s})}+\mathrm{H}_{2} \mathrm{O}_{(\mathrm{g})}
$$

\section{- RESULTS AND DISCUSSION}

\section{Thermal Analysis}

Fig. 1 shows the TG-DTA curves of the hydrous zirconia, $\mathrm{ZrO}(\mathrm{OH})_{2}$ after it was dried at $150^{\circ} \mathrm{C}$. The TGDTA curve exhibited several endothermic peaks below $1000^{\circ} \mathrm{C}$ which indicates that the samples obtained would be denatured at a temperature of $765.8^{\circ} \mathrm{C}$. However, the sample structures illustrate that the samples calcined at more than $700{ }^{\circ} \mathrm{C}$ had started to melt, as shown in Fig. $7(\mathrm{c})$, and hardened when they were cooled at room temperature. Based on the DSC curves, the melting point of $\mathrm{ZrO}(\mathrm{OH})_{2}$ was $59.94{ }^{\circ} \mathrm{C}$. The melting point of $\mathrm{ZrO}(\mathrm{OH})_{2}$ should be $318{ }^{\circ} \mathrm{C}$ [13]. This result showed that the presence of impurity components added during the synthesis of $\mathrm{ZrO}(\mathrm{OH})_{2}$, such as ammonium ion, had accelerated the degradation of the polymeric network, while the chloride ions that had affected the thermal stability of caustic fusion were not significant, compared to the ammonium ions.

\section{Crystallization}

Fig. 2 shows XRD patterns of the samples that were prepared at different temperatures in the calcination process, which ranged from 500 to $800{ }^{\circ} \mathrm{C}$ for both the synthesized and commercial zirconia powders. The XRay diffractogram showed two monoclinic phases of nanocrystalline zirconia $28.1^{\circ}$ (111), 31.4 ${ }^{\circ}$ (111) (JCPDS card no.78-1807) and tetragonal $30.2^{\circ}$ (101), 50.2 (112) and $60.2^{\circ}(211)$ (JCPDS card 79-2769) [14].

In Fig. 2(b) to (e), based on the samples used, the $\mathrm{X}$-Ray pattern on the line of the synchrotron beam showed

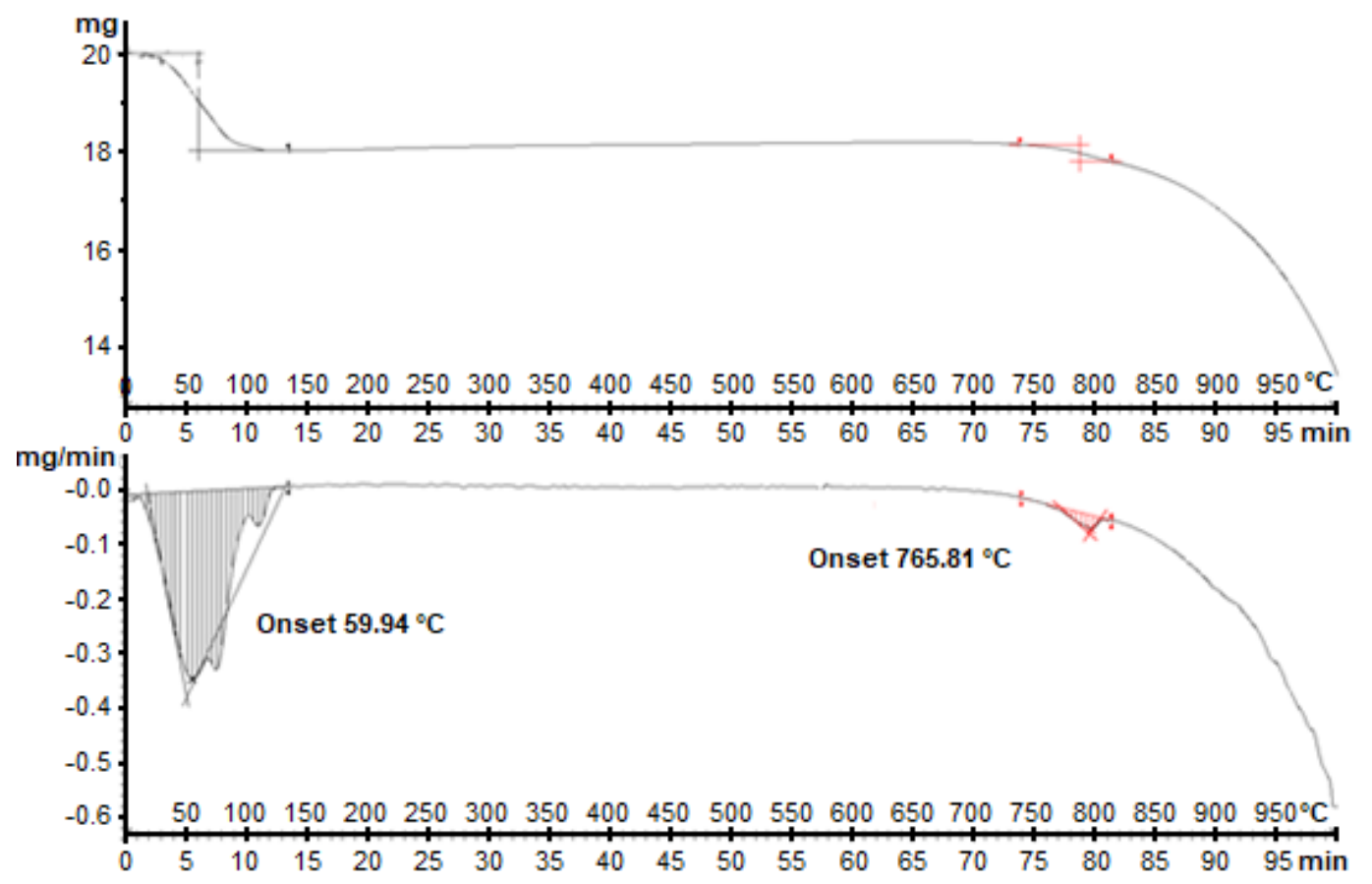

Fig 1. TG-DTA curves of the hydrous zirconia, $\mathrm{ZrO}(\mathrm{OH})_{2}$ precipitated after dried at $150{ }^{\circ} \mathrm{C}$ 


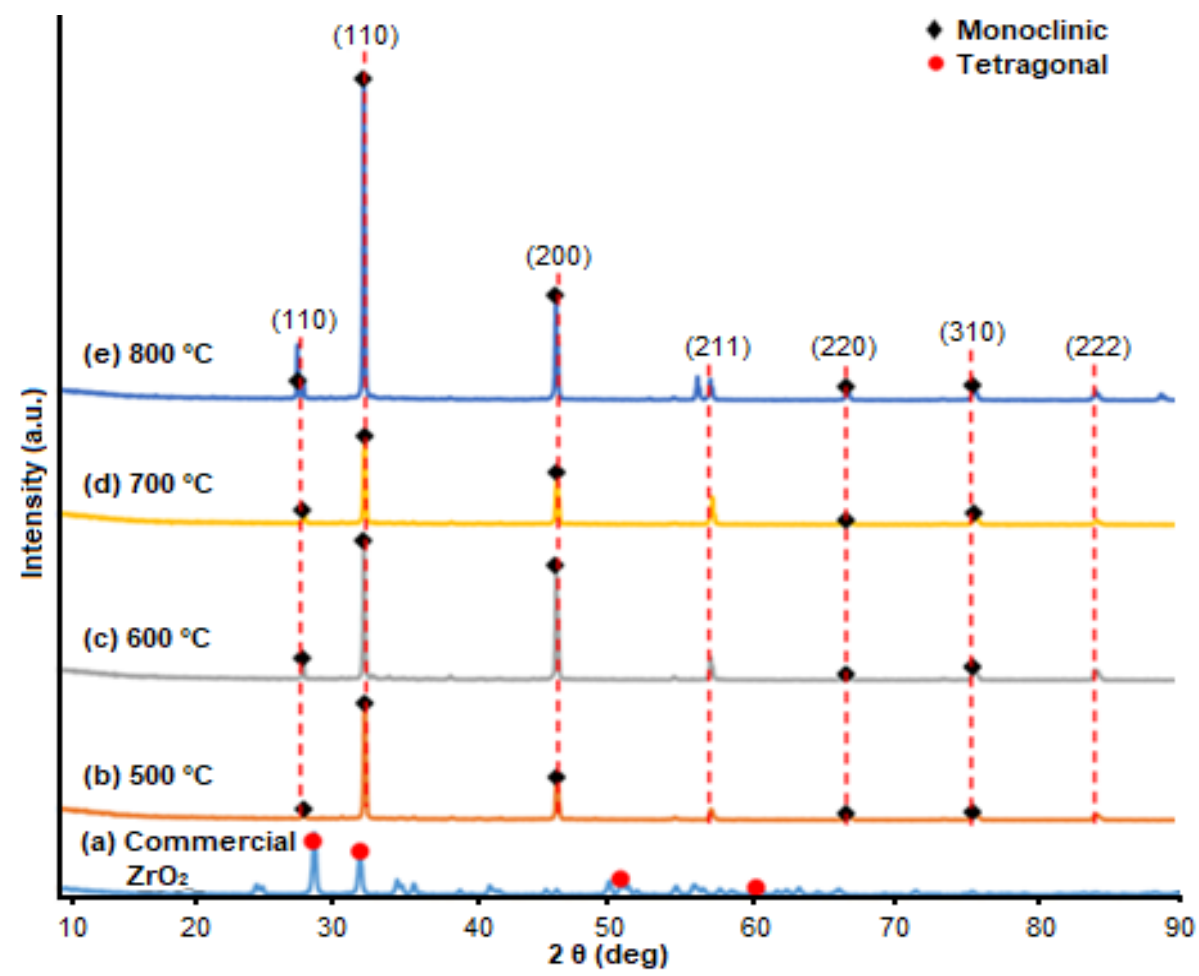

Fig 2. XRD patterns for commercial zirconia and hydrous zirconia, $\mathrm{ZrO}(\mathrm{OH})_{2}$ after calcination at various temperature

that the synthesized zirconia was a nearly pure monoclinic zirconia (>95\%) [15]. The synthesized zirconia did not possess the tetragonal structure because the calcination temperature was not above $1170{ }^{\circ} \mathrm{C}$, based on the XRD pattern obtained. Fig. 3 shows the three crystallographic structures that occurred in pure zirconia [18]. First, the monoclinic form that remained stable until $1170{ }^{\circ} \mathrm{C}$. Second, the tetragonal form that remained stable between 1170 and $2370{ }^{\circ} \mathrm{C}$. Third, the cubic form that remained stable above $2370{ }^{\circ} \mathrm{C}$. The volumetric expansion of 3-5\% is related to both martensitic natures in considerable technological importance in the changes of zirconia from tetragonal to monoclinic structure [16]. Afterwards, the significant effect of calcination on the phase purity of the zirconia powder was determined. Thirty two percent of the total zirconia was in the monoclinic phase and above $1170{ }^{\circ} \mathrm{C}$, in which it will totally change to the tetragonal form. Then, during the calcination process, the presence of cations was resulted from the migration of cations when the existing diffusion pathway was inactivated or not fully in the crystalline phase. This is because the transformation process is indicated by the endothermic peak and is irreversible [17].
However, the preparation of synthesized zirconia can affect its structure. The material was prepared using zircon sand and produced at a $\mathrm{pH}$ of 10 when the precipitation was formed, which means it was able to obtain a high percentage of monoclinic form. A medium $\mathrm{pH}$ range (8-11) could produce monoclinic zirconia, while a low $\mathrm{pH}(3-5)$ and high $\mathrm{pH}$ range (13-14) produces tetragonal phase based on previous researches [15]. This is because the initial zirconium species are well detached,

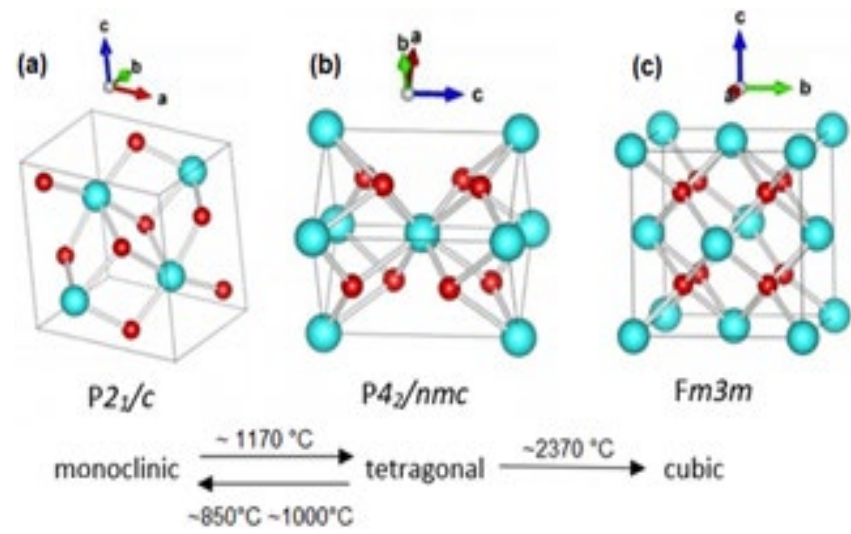

Fig 3. Zirconia phase transformations. As the temperature increases, the zirconia transforms from (a) monoclinic to (b) tetragonal to (c) cubic [18] 
and could probably be because it is a monoatomic species of the zirconium [15]. The application for monoclinic structure can be used for components in refractory materials, molten metal filters, additive to mixed oxide systems, and nozzles and stoppers of transfer/holding ladles.

Meanwhile, the commercial zirconia contained tetragonal zirconia at a high percentage. The commercial zirconia had fully changed from the monoclinic to tetragonal form since the thermal treatment of the commercial zirconia was above $1170{ }^{\circ} \mathrm{C}$. Within the temperature of 1170 to $2300{ }^{\circ} \mathrm{C}$, the zirconia was in a stable tetragonal form [19-20]. The effect of $\mathrm{pH}$ can be the main factor for the zirconia produced in the tetragonal phase because it can be obtained at either a low $\mathrm{pH}(3-5)$ or high $\mathrm{pH}$ (13-14) range [15].

\section{Particle Size and Morphology}

The particle size distribution parameters of the synthesized zirconia powder are shown in Fig. 4. Usually, the most significant aspect in the particle size distribution is the three-point distribution, nominated as $\mathrm{D}_{10}, \mathrm{D}_{50}$, and $\mathrm{D}_{90}$ using Eq. (5).

$$
S_{\mathrm{w}}=\frac{2.56}{\log _{10}\left(\frac{\mathrm{D}_{90}}{D_{10}}\right)}
$$

The ideal condition of the value $S_{w}$ can either be less than 2 or greater than 7 , showing a very broad $\left(S_{w}=2\right.$ or $\left.\mathrm{D}_{90}=19 \mathrm{D}_{10}\right)$ or very narrow distribution $\left(\mathrm{S}_{\mathrm{w}}=7\right.$ or $\mathrm{D}_{90}=$ $2.3 \mathrm{D}_{10}$ ) [21]. Based on the results tabulated in Table 2, the synthesized particle width distributions were 4.52, 2.26, 2.81 , and 5.53, where they correspond to a broad distribution because their $S_{w}$ was less than 7. For the commercial zirconia, the $S_{w}$ value was 2.49 . The particle width distribution and specific surface area of zirconia and commercial zirconia at $600{ }^{\circ} \mathrm{C}$ were almost similar, which were 0.1350 and $0.1310 \mathrm{~m}^{2} / \mathrm{g}$, respectively. The results obtained from this analysis showed that the zirconia powder could be synthesized by using zircon sand. By using commercial zirconia as an indicator, it is possible to determine if the powder produced is similar to the commercial one or otherwise.

Fig. 5 shows that the increase of temperature made the particle size distribution less narrow, except for the synthesis of zirconia at a temperature of $600{ }^{\circ} \mathrm{C}$. Calcination temperature influences the size of the zirconia and densification of the samples. However, in this result, the value of the specific surface area was not consistent. The smaller the size, the larger the specific surface area. The particle size of the powder is directly dependent on the calcination temperature because at high temperatures, shrinkage is likely to occur on the zirconia [22]. From the observation made, the lower the calcination temperature, the narrower the distribution.

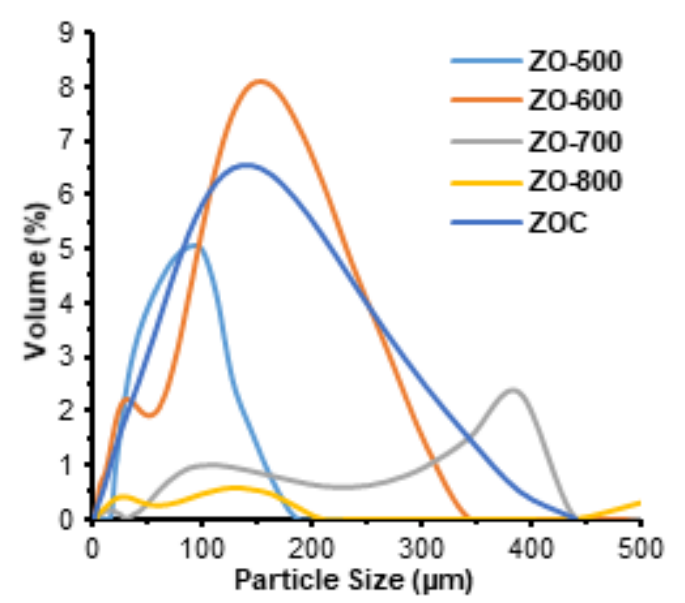

Fig 4. Particle size distribution for synthesized zirconia powder of different temperatures of calcination

Table 2. Parameter of the particle size distribution

\begin{tabular}{lrcccc}
\hline \multirow{2}{*}{$\mathrm{ZrO}_{2}$ powder } & \multicolumn{3}{c}{ Particle size $(\mu \mathrm{m})$} & $\begin{array}{c}\text { Particle width } \\
\text { distribution }\left(\mathrm{S}_{\mathrm{w}}\right)\end{array}$ & $\begin{array}{c}\text { Specific surface } \\
\text { area }\left(\mathrm{m}^{2} / \mathrm{g}\right)\end{array}$ \\
\cline { 2 - 5 } $\mathrm{ZrO}_{2} 500^{\circ} \mathrm{C}$ & 38.725 & 121.380 & 142.802 & 4.52 & 0.0635 \\
$\mathrm{ZrO}_{2} 600^{\circ} \mathrm{C}$ & 21.928 & 153.055 & 299.111 & 2.26 & 0.1350 \\
$\mathrm{ZrO}_{2} 700^{\circ} \mathrm{C}$ & 190.251 & 930.022 & 1546.454 & 2.81 & 0.0268 \\
$\mathrm{ZrO}_{2} 800^{\circ} \mathrm{C}$ & 507.257 & 993.615 & 1473.014 & 5.53 & 0.0288 \\
${\mathrm{Commercial} \mathrm{ZrO}_{2}}^{23.645}$ & 110.514 & 252.177 & 2.49 & 0.1310 \\
\hline
\end{tabular}


Primary distribution of the particles are broaden with the equivalent of decreasing volume fraction, as the calcination temperature increases [22]. In Fig. 5, the influence of the particle size on the phase of zirconia is shown when the calcination had been completed to produce zirconia. The calcination temperature had affected the size of the distribution in which the highest surface area was obtained at calcination temperature of $600^{\circ} \mathrm{C}$. This is probably because the zirconia was defined as amorphous zirconia due to its high surface area and the presence of small particles, as well as the presence of the surfactant that can be induced [23]. However, the particle size is probably the influencing factor because the embryonic nuclei is responsible for the nature of the phase obtained. Improvement on the digested zirconia had increased its resistance to thermal calcination of up to $800^{\circ} \mathrm{C}$ when compared to the undigested zirconia. As the time of digestion increased, the loss in the surface area decreased with calcination temperature up to $800^{\circ} \mathrm{C}$ [24]. Hence, the smallest particle size width was 2.26 , which was synthesized zirconia at $600^{\circ} \mathrm{C}$, that also had the largest specific surface area of $0.1350 \mathrm{~m}^{2} / \mathrm{g}$, in which it is almost similar to that of the commercial zirconia at $0.1310 \mathrm{~m}^{2} / \mathrm{g}$.

In the BET analysis, the specific surface area, $\mathrm{S}_{\mathrm{BET}}$, and pore distribution were determined. In Table 3, parameters of the BET analysis of the synthesized zirconia are stated.

The highest BET surface area of the synthesized zirconia was $1.8915 \mathrm{~m}^{2} / \mathrm{g}$, which was calcined at $700{ }^{\circ} \mathrm{C}$, and the lowest surface area was $0.6811 \mathrm{~m}^{2} / \mathrm{g}$ at $600^{\circ} \mathrm{C}$. For the total volume in pores, the highest was $0.00439 \mathrm{~m}^{3} / \mathrm{g}$, belonging to the synthesized zirconia at $600{ }^{\circ} \mathrm{C}$, and the lowest was $0.00147 \mathrm{~m}^{3} / \mathrm{g}$. However, as the calcination temperature increased, the total area in pores of the synthesized zirconia also increased.

Fig. 6 shows the surface area against the pore width of the synthesized zirconia calcined at 500,600, 700, and
$800{ }^{\circ} \mathrm{C}$. The pore width widened with increasing calcination temperature, except for the synthesized zirconia calcined at $600{ }^{\circ} \mathrm{C}$. The pore width reached the largest value with an incremental surface area when the synthesized zirconia was calcined at $600{ }^{\circ} \mathrm{C}$. The graph pattern for the synthesized zirconia at 600,700 , and $800{ }^{\circ} \mathrm{C}$ were unimodal, and for the synthesized zirconia at $500{ }^{\circ} \mathrm{C}$, it was bimodal. The synthesized powders contained voids or pores. In addition, the particle's slow growth is a direct influence to its loose porous structure

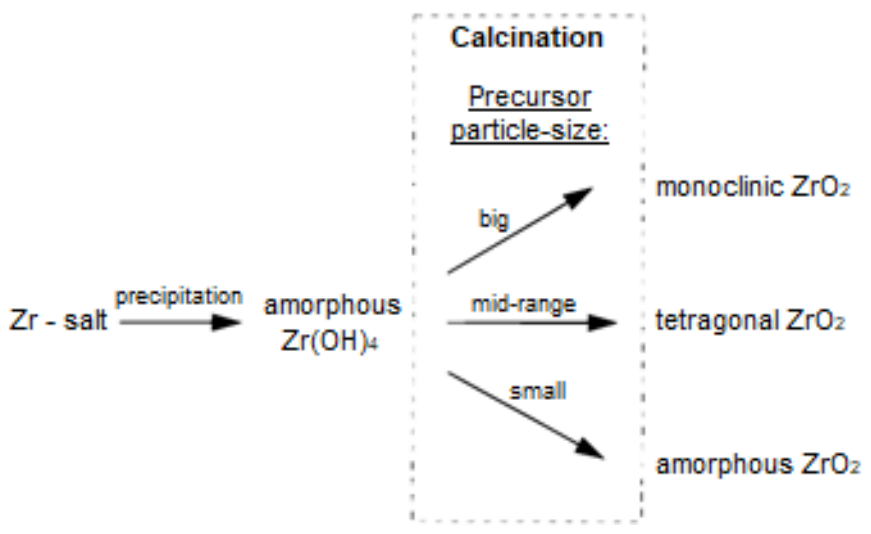

Fig 5. Influence of the precursor particle size on the phase of zirconia [23]

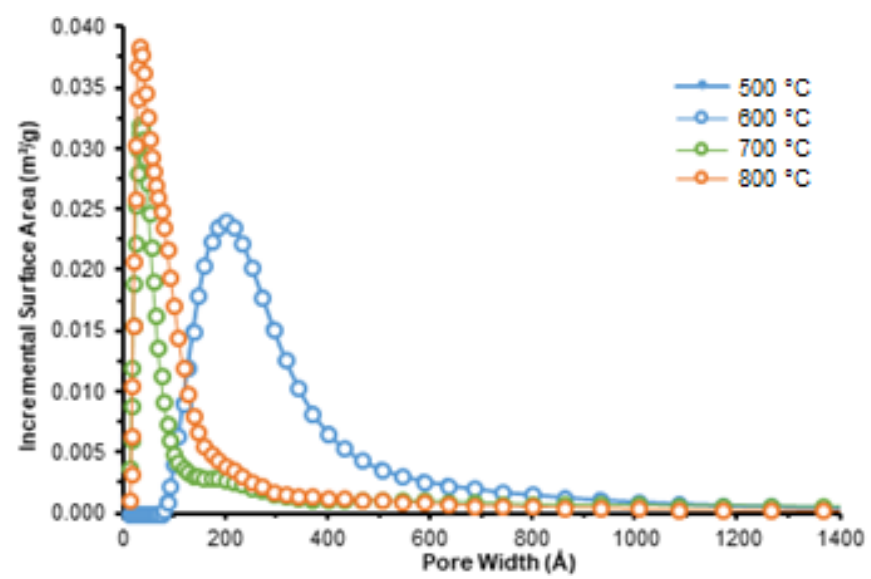

Fig 6. Surface area against pore width of synthesized zirconia at different calcination temperatures

Table 3. Parameter of the BET analysis

\begin{tabular}{lccc}
\hline $\mathrm{ZrO}_{2}$ Powder & BET surface area, $\mathrm{S}_{\mathrm{BET}}\left(\mathrm{m}^{2} / \mathrm{g}\right)$ & Total area in pores $\left(\mathrm{m}^{2} / \mathrm{g}\right)$ & Total volume in pores $\left(\mathrm{m}^{3} / \mathrm{g}\right)$ \\
\hline $\mathrm{ZrO}_{2} 500^{\circ} \mathrm{C}$ & 1.0721 & 0.239 & 0.00147 \\
$\mathrm{ZrO}_{2} 600^{\circ} \mathrm{C}$ & 0.6811 & 0.329 & 0.00439 \\
$\mathrm{ZrO}_{2} 700^{\circ} \mathrm{C}$ & 1.8915 & 0.546 & 0.00205 \\
$\mathrm{ZrO}_{2} 800^{\circ} \mathrm{C}$ & 1.5074 & 0.750 & 0.00268 \\
\hline
\end{tabular}


and the ability to sustain its amorphous nature during calcination of up to $500{ }^{\circ} \mathrm{C}$ [25]. At $600{ }^{\circ} \mathrm{C}$, the intermediate temperature for zirconia transformed the phase from an amorphous to crystalline nature of $\mathrm{t}$-zirconia, and at $800{ }^{\circ} \mathrm{C}$, stabilization was found for t-zirconia with a porous structure [25]. An assumption can be made that ceramics with spherical shape and large pores had caused the presence of particles with hollow spherical shape in the source powder since the average size of the powder corresponds to large pores with an average size in calcined materials [26].

Table 4 indicates the chemical composition of $\mathrm{ZrO}_{2}$ samples at different calcination temperatures and also the composition of commercial zirconia. The results showed that the synthesized zirconia could produce the highest amount of $\mathrm{ZrO}_{2}$ at a temperature of $600{ }^{\circ} \mathrm{C}$, which was $54.48 \%$. The amount of $\mathrm{Na}_{2} \mathrm{O}$ in synthesized zirconia was too large. However, the amount of $\mathrm{Na}$ substance in zirconia is detrimental to its strength and ionic conductivity, which is an important characteristic of zirconia-based materials [27]. The importance of zirconia containing a high amount of $\mathrm{Na}$ can also be seen in when it is used in the thermal barrier, making the high content of sodium in powders acceptable [27]. This can be correlated to the chemical composition of zircon sand in Table 1. The composition of zirconium ions inside the sand was not pure, due to the presence of other substances which affect the purity of the synthesized zirconia.

Fig. 7 shows the SEM images for the surface and topography of zirconia, synthesized at different calcination temperatures, and also images of commercial zirconia. The structure in Fig. 7(a) showed an amorphous-like structure because it is unlikely to be crystalline. Meanwhile, the differences in Fig. 7(c) and 7 (d) are that the shape of the agglomerated powder was reduced when the temperature of calcination increased. Furthermore, Fig. 7(b) showed a similarity in shape with that in Fig. 7(e). The powders calcined at $600^{\circ} \mathrm{C}$ had the same shape as commercial zirconia. Based on this observation, the synthesis of zirconia powder can be performed using zircon sand when calcined at $600^{\circ} \mathrm{C}$. However, the structure of zirconia calcined at more than

Table 4. Chemical composition of $\mathrm{ZrO}_{2}$ samples

\begin{tabular}{lcccc}
\hline \multirow{2}{*}{ Samples } & \multicolumn{4}{c}{ XRF Chemical Composition (wt.\%) } \\
\cline { 2 - 5 } & $\mathrm{ZrO}_{2}$ & $\mathrm{Na}_{2} \mathrm{O}$ & $\mathrm{SiO}_{2}$ & $\mathrm{CaO}$ \\
\hline $\mathrm{ZrO}_{2} 500{ }^{\circ} \mathrm{C}$ & 51.53 & 43.77 & 7.59 & 0.18 \\
$\mathrm{ZrO}_{2} 600^{\circ} \mathrm{C}$ & 54.48 & 46.40 & 7.86 & 0.23 \\
$\mathrm{ZrO}_{2} 700{ }^{\circ} \mathrm{C}$ & 53.58 & 41.20 & 12.09 & 0.30 \\
$\mathrm{ZrO}_{2} 800^{\circ} \mathrm{C}$ & 52.41 & 35.72 & 16.33 & 0.36 \\
Commercial $\mathrm{ZrO}_{2}$ & 100 & - & - & - \\
\hline
\end{tabular}

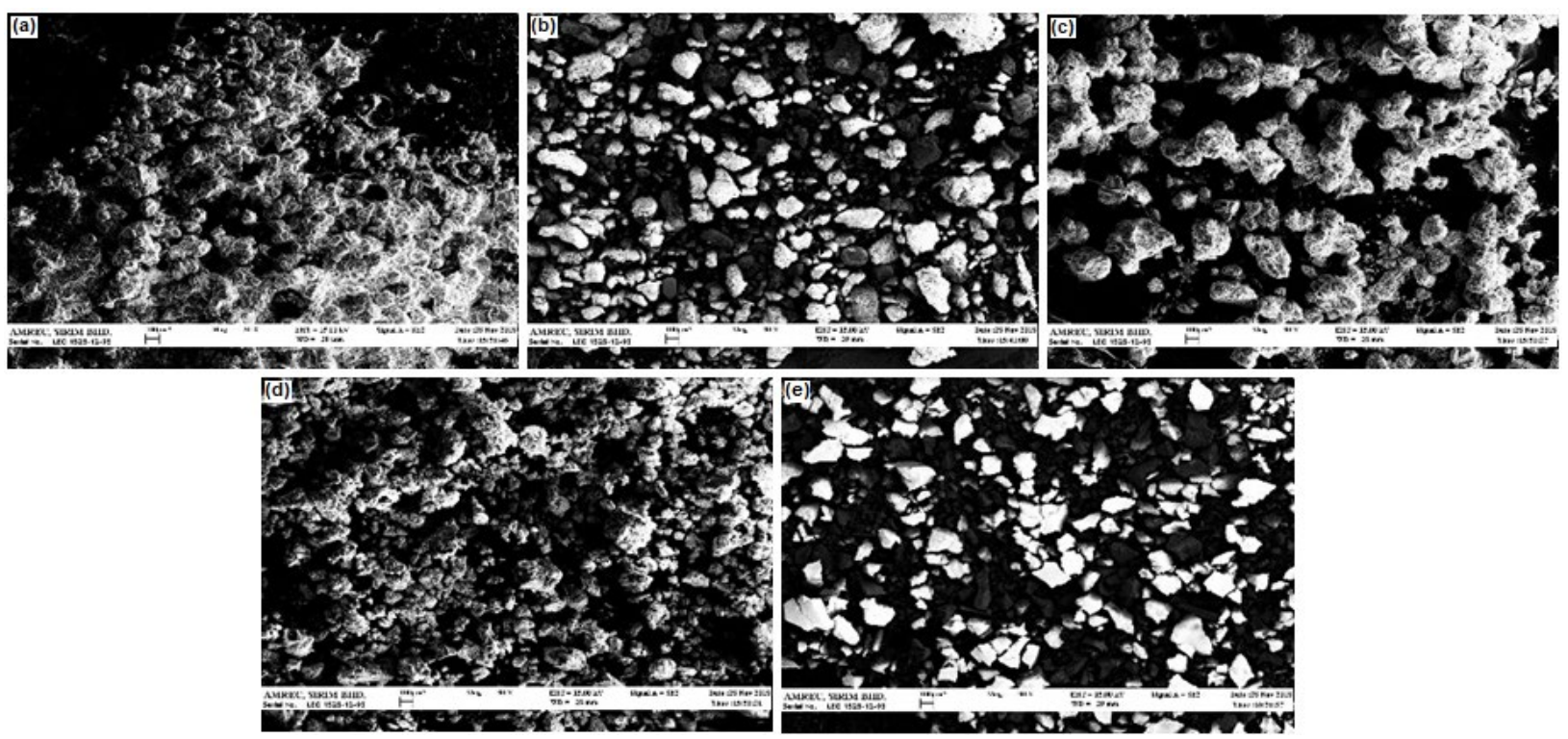

Fig 7. SEM images of (a) synthesized zirconia at $500^{\circ} \mathrm{C}$, (b) synthesized zirconia at $600{ }^{\circ} \mathrm{C}$, (c) synthesized zirconia at $700{ }^{\circ} \mathrm{C}$, (d) synthesized zirconia at $800^{\circ} \mathrm{C}$, and (e) commercial zirconia 
$700{ }^{\circ} \mathrm{C}$ showed that the structure becomes denatured because it will start to melt at that temperature.

Based on a previous study, the calcination of local zircon sand from Indonesia using the same method of synthesis, which is the caustic fusion method, at calcination temperature of higher than $500{ }^{\circ} \mathrm{C}$ gives good ionic conductivity [13]. The slopes of zirconia calcined between 600 to $700{ }^{\circ} \mathrm{C}$ showed the greatest ionic conductivity based on their researches [13]. However, in this study, the synthesis of the zirconia differs from what was performed in the previous study. In the present study, the synthesis of zirconia was conducted using different raw materials, which was the zircon sand supplied from Zircon Minerals Malaysia Sdn. Bhd. However, the same method of synthesis was successfully applied to synthesize the zirconia. The results obtained showed that zirconia calcined at $600^{\circ} \mathrm{C}$ had produced an almost similar structure with commercial zirconia. In addition, other characteristics, such as the surface area and pore volume of the synthesized zirconia, were the greatest when compared with other zirconia.

\section{- CONCLUSION}

The synthesized zirconia powder can be produced from a caustic fusion method using the raw material of zircon sand. Based on the results using the XRD analysis, BET, SEM, and by investigating the particle size of the synthesized zirconia powder, it was shown that the obtained powder had achieved almost similar characteristics to that of the commercial powder. However, the structure of the synthesized and commercial zirconia based on the XRD analysis was different in which the synthesized zirconia was in a monoclinic structure, while the commercial zirconia was in tetragonal. The SEM images, showed that the structures were the same for both powders. This is proven from observing the particle size width and specific surface area, where results for both powders were almost the same. Hence, the synthesis of zirconia powder using the zircon sand supplied from Zircon Minerals Malaysia Sdn. Bhd. was successful.

\section{- ACKNOWLEDGMENTS}

The authors would like to express gratitude for the financial support given under the Fundamental Research Grant Scheme (FRGS, 600-RMI/FRGS 5/3 (457/2019) from Universiti Teknologi MARA (UiTM), Malaysia. The authors would also like to extend our appreciation to the Zircon Minerals Malaysia for providing the Australian Zircon Sand as a raw material for this project.

\section{- REFERENCES}

[1] Sommers, A., Wang, Q., Han, X., T'Joen, C., Park, Y., and Jacobi, A., 2010, Ceramics and ceramic matrix composites for heat exchangers in advanced thermal systems-A review, Appl. Therm. Eng., 30 (11-12), 1277-1291.

[2] Gerhardt, L.C., and Boccaccini, A.R., 2010, Bioactive glass and glass-ceramic scaffolds for bone tissue engineering, Materials, 3 (7), 3867-3910.

[3] Mihai, L.L., Parlatescu, I., Gheorghe, C., Andreescu, C., Bechir, A., Pacurar, M., and Cumpata, C.N., 2014, In vitro study of the effectiveness to fractures of the aesthetic fixed restorations achieved from zirconium and alumina, Rev. Chim., 65 (6), 725-729.

[4] Bocanegra-Bernal, M.H., and de la Torre, S.D., 2002, Phase transitions in zirconium dioxide and related materials for high performance engineering ceramics, J. Mater. Sci., 37 (23), 4947-4971.

[5] Daou, E.E., 2014, The zirconia ceramic: Strengths and weaknesses, Open Dent. J., 8, 33-42.

[6] Della Bona, A., Pecho, O.E., and Alessandretti, R., 2015, Zirconia as a dental biomaterials, Materials, 8 (8), 4978-4991.

[7] Sōmiya, S., and Akiba, T., 1999, Hydrothermal zirconia powders: A Bibliography, J. Eur. Ceram. Soc., 19 (1), 81-87.

[8] Kljajević, L., Matović, B., Radosavljević-Mihajlović, A., Rosić, M., Bosković, S., and Devečerski, A., 2011, Preparation of $\mathrm{ZrO}_{2}$ and $\mathrm{ZrO}_{2} / \mathrm{SiC}$ powders by carbothermal reduction of $\mathrm{ZrSiO}_{4}$, J. Alloys Compd., 509 (5), 2203-2215.

[9] Yamagata, C., Andrade, J.B., Ussui, V., de Lima, N.B., and Paschoal, J.O.A., 2008, High purity zirconia and silica powders via wet process: Alkali fusion of zircon sand, Mater. Sci. Forum, 591-593, 771-776.

[10] Götsch, T., Wallisch, W., Stöger-Pollach, M., Klötzer, B., and Penner, S., 2016, From zirconia to yttria: Sampling the YSZ phase diagram using 
sputter-deposited thin films, AIP Adv., 6 (2), 025119.

[11] Rahmawati, F., Permadani, I., Soepriyanto, S., Syarif, D.G., and Heraldy, E., 2014, Double steps leaching and filtration in caustic fusion method to produce zirconia from local zircon concentrate, Proceedings of the 2014 International Conference on Physics and its Applications (ICOPIA-14), 99-102.

[12] Rahmawati, F., Permadani, I., Heraldy, E., Syarif, D.G., and Soepriyanto, S., 2016, Structure and morphological analysis of various composition of yttrium doped-zirconia prepared from local zircon sand, J. Phys. Conf. Ser., 776 (1), 012050.

[13] Apriany, K., Permadani, I., Syarif, D.G., Soepriyanto, S., and Rahmawati, F., 2016, Electrical conductivity of zirconia and yttrium-doped zirconia from Indonesian local zircon as prospective material for fuel cells, IOP Conf. Ser.: Mater. Sci. Eng., 107, 012023.

[14] Gusain, D., Singh, P.K., and Sharma, Y.C., 2016, Kinetic and equilibrium modelling of adsorption of cadmium on nano crystalline zirconia using response surface methodology, Environ. Nanotechnol. Monit. Manage., 6, 99-107.

[15] Srinivasan, R., De Angelis, R.J., Ice, G., and Davis, B.H., 1991, Identification of tetragonal and cubic structures of zirconia using synchrotron x-radiation source, J. Mater. Res., 6 (6), 1287-1292.

[16] Oliveira, A.P., and Torem, M.L., 2001, The influence of precipitation variables on zirconia powder synthesis, Powder Technol., 119 (2-3), 181-193.

[17] Gauna, M.R., Conconi, M.S., Gómez, S., Suárez, G., Aglietti, E.F., and Rendtorff, N.M., 2015, Monoclinic-tetragonal zirconia quantification of commercial nanopowder mixtures by XRD and DTA, Ceram.-Silik., 59 (4), 318-325.

[18] Brog, J.P., Chanez, C.L., Crochet, A., and Fromm, K.M., 2013, Polymorphism, what it is and how to identify it: A systematic review, RSC Adv., 3 (38), 16905-16931.

[19] Ning, S., Zhan, P., Xie, Q., Li, Z., and Zhang, Z., 2013, Room-temperature ferromagnetism in undoped $\mathrm{ZrO}_{2}$ thin films, J. Phys. D: Appl. Phys., 46 (44), 445004.

[20] Simione, D., Baldinozzi, G., Gosset, D., Dutheil, M., Bulou, A., and Hansen, T., 2003, Monoclinic to tetragonal semireconstructive phase transition of zirconia, Phys. Rev. B, 67 (6), 064111.

[21] Zauner, R., 2006, Micro powder injection moulding, Microelectron. Eng., 83 (4-9), 1442-1444.

[22] Yaqub, A., Savaniu, C., Janjua, N., and Irvine, J., 2013, Preparation via a solution method of $\mathrm{La}_{0.2} \mathrm{Sr}_{0.25} \mathrm{Ca}_{0.45} \mathrm{TiO}_{3}$ and its characterization for anode supported solid oxide fuel cells, J. Mater. Chem. A, 1 (45), 14189-14197.

[23] Stichert, W., and Schüth, F., 1998, Influence of crystallite size on the properties of zirconia, Chem. Mater., 10 (7), 2020-2026.

[24] Chuah, G.K., and Jaenicke, S., 1997, The preparation of high surface area zirconia Influence of precipitating agent and digestion, Appl. Catal., A, 163 (1-2), 261-273.

[25] Nayak, N.B., and Nayak, B.B., 2016, Temperaturemediated phase transformation, pore geometry and pore hysteresis transformation of borohydride derived in-born porous zirconium hydroxide nanopowders, Sci. Rep., 6, 26404.

[26] Buyakova, S., Sablina, T., and Kulkov, S., 2015, Porosity and mechanical properties of zirconium ceramics, AIP Conf. Proc., 1688 (1), 030009.

[27] Manivasakan, P., Rajendran, V., Rauta, P.R., Sahu, B.B., and Panda, B.K., 2011, Synthesis of monoclinic and cubic $\mathrm{ZrO}_{2}$ nanoparticles from zircon, J. Am. Ceram. Soc., 94 (5), 1410-1420. 